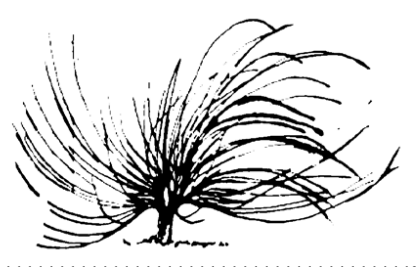

\title{
The Significance of Teaching English for Specific Purposes in Costa Rica
}

\author{
Keilyn G. Gamboa Agüerol \\ Universidad Nacional \\ Costa Rica \\ k8gamboa@gmail.com \\ Scarleth P. Rodríguez Rodríguez ${ }^{2}$ \\ Universidad Nacional \\ Costa Rica \\ scarlethr9@gmail.com
}

\begin{abstract}
This essay aims at analyzing the significance of the English for Specific Purposes (ESP) approach in Costa Rica. In addition, the authors scrutinized and compared different sources, such as journals, digital books, web pages, and others in order to provide relevant information regarding ESP, for instance, the aim of ESP based on its definition, its types, its objectives, and the effects of the absence of this approach in the learning process and the curriculum of the students as future employees, considering that Costa Rica does not have enough specialists in the area yet. Some programs to teach the target language for different majors need to be redesigned in order to guarantee the students a learning process based on the professional profile that they want to achieve, their needs, and their professional field. Likewise, this paper also explains the effects of the lack of ESP in the country. Hence, contemplating the effectiveness of making use of
\end{abstract}

Recibido: 1 de agosto de 2020. Aprobado: 1 de junio de 2021

http://dx.doi.org/10.15359/rep.16-2.7

1 Senior student. Universidad Nacional, Sede Regional Brunca, Campus Coto. ORCID ID: https://orcid.org/0000-0002-6382-3851

2 Senior student. Universidad Nacional, Sede Regional Brunca, Campus Coto. ORCID ID: https://orcid.org/0000-0001-8490-4194 
ESP to learn the target language can allow the education system of the country to take advantage of the benefits and opportunities that ESP represents for the nation.

Keywords: English for Specific Purposes, Costa Rica, significance, aim, effects

\section{Resumen}

Este ensayo tiene como objetivo analizar la importancia del método inglés con fines específicos (IFE) en Costa Rica. Además, las autoras analizaron y compararon diferentes fuentes como revistas académicas, libros digitales, páginas web y otras, para proveer información relacionada con el IFE, por ejemplo: la definición del IFE, sus tipos, objetivos y los efectos de la ausencia de este enfoque en el proceso de aprendizaje y el currículum de las personas estudiantes como futuras empleadas, ya que Costa Rica no tiene suficientes profesionales especializados en el área. Algunos programas dirigidos a enseñar la lengua meta para diferentes carreras necesitan ser rediseñados, con miras a garantizar al estudiantado un proceso de aprendizaje basado en el perfil profesional que quiere alcanzar, sus necesidades y sus campos profesionales. Asimismo, este trabajo brinda algunas posibles soluciones, al considerar la ausencia del IFE en el país. Por lo tanto, contemplar la efectividad de hacer uso del IFE para aprender la lengua meta permite que el sistema educativo aproveche los beneficios y oportunidades que el IFE representa para la nación.

Palabras clave: Inglés con fines específicos, Costa Rica, importancia, objetivo, efectos

\section{Introduction}

\footnotetext{
Turrently, English for Specific Purposes (ESP) is part of the education system of Costa Rica; therefore, the aim of this paper is to analyze the significance of this approach for this developing country. Costa Rica has sought development in its economy for years, and, consequently, it has been trying to look for a more efficient labor market. In the world, ESP began some decades ago; in fact, Barrantes (2009) demonstrated that "it started in the 1960s as a
} 
result of developments in Linguistics and in Educational Psychology, and it is based on designing courses to meet specific learners' needs" (p. 2). However, by 2006, the education system in Costa Rica started to note the necessity of implementing ESP in order to improve the English level of people from different fields. Hernández (2008) explained that, in 2006 and 2007, the School of Modern Languages of the University of Costa Rica (UCR) conducted a research project whose main objective was to analyze the abilities that English teachers from UCR needed to meet the necessities of the country so that those skills could be used for the teaching practicum course of the Master's Program in English Teaching as a Foreign Language. The research had two goals: a) to implement a diagnosis with the current necessities of the country regarding English teaching to determine the abilities that are required for English teachers and b) to develop a guide with the results obtained to take them into consideration for this teaching practicum.

On the other hand, Costa Rica has been working on being a bilingual country, but it copes with some challenges to teach English, and regarding the needs of every field, the requirements are greater. Saborio and Valenzuela (2009) admitted that "professors of teaching English as a foreign language have taught courses of English for other majors, even though these educators have not been specialized in ESP" (p. 4). The education system of the country has contemplated the significance of having professionals in the area of ESP because it is an opportunity for Costa Rican citizens to learn specialized English properly. Actually, according to the different professional profiles, some English programs require to be redesigned for students to develop the linguistic competences that enable them to learn the target language. Indeed, engineering students declared that there is a need to regulate their English programs due to the fact that speaking this language is relevant at the moment of being hired (Quesada \& Zamora, 2018). Unfortunately, the case mentioned above is an example of the situation that different majors face in their learning process. Therefore, in order to emphasize how necessary ESP is in Costa Rica, it is imperative to comprehend its aim, to assess the effects of its absence in the education of Costa Rican citizens, and to understand its significance for this developing country. 


\section{Comprehending the Aim of ESP}

Due to the important role that ESP plays in the English teaching for specific fields, being aware of its concept could help people know how necessary ESP is to learn the target language. This perspective is supported by González (2015), who stated that "English for Specific Purposes has become a fruitful field over the last three decades. As a learner-centered approach, its main purpose has been to fulfill the specific needs of target learners to satisfy either their professional or vocational demands" (p. 2). Moreover, Manley et al. (2019) declared that the aim of ESP is to provide linguistic skills to a group of professionals who need to develop those abilities centered on the target language in order to perform tasks related to their discipline. Likewise, Barrantes (2009) affirmed that a needs analysis is required to develop an ESP course because it is based on obtaining information about both current performance and target performance. Hence, ESP is an approach whose purpose is to teach English contemplating an analysis of the needs that each course requires regarding a specific discipline. On the whole, ESP is an approach applied in order to provide an appropriate teaching process of the target language according to the needs and the profile of the learners and their professional field.

ESP is divided into two different types: English for Academic Purposes (EAP) and English for Occupational Purposes (EOP), and they are addressed to fulfill the necessities of different fields. Based on Sarmento and Bocorny (2018), English for occupational purposes refers to English for call center operators, English for bank tellers, English for servers, while English for academic purposes is about preand in-sessional English language support offered at universities where English is the language of instruction. Thus, while EAP is as a school subject, EOP is a vocational and professional subject. Likewise, Dudley and John's study of 1998 (as cited in Rodríguez, 2006) referred to the concepts EOP and EAP as branches derived from ESP: (a) English for Occupational Purposes is aimed at courses for professional, vocational, and pre-work purposes and (b) English for Academic Purposes is related to courses for the areas of Science and Technology, Law, Medicine, and Business. In general, Sarmento and Bocorny (2018) and Rodriguez (2006) agreed on the definitions of the concepts. Also, despite the fact 
that EOP and EAP share some similar goals and aims, the means to reach their objectives are different.

ESP implies determined objectives which make this approach relevant to teach English for Specific Purposes. Basturkmen (2010, p. 3 ) indicated that "...ESP courses focus on work- or study-related needs, not personal needs or general interests." Hence, the learning contexts of the students have to be considered, and the learners have to be active participants of their own learning process. Moreover, Acosta et al. (2005) stated:

When talking about course objectives in an ESP context, the main aspects to consider are how feasible and realistic the objectives are in terms of the abilities of the target population and the time available, how objectives resemble the competences students will need in their professional or academic life and the relationship between goals and students' expectations. (p. 5)

Acosta et al. (2005) agreed on the fact that the most significant objective that ESP involves is to contemplate the professional profile that the learners have to reach in order to achieve a successful learning process.

Analyzing the needs of the learners considering the aim of ESP at the moment of teaching English is crucial for the development of this approach in a develping country such as Costa Rica. Hutchinson and Waters (1987) claimed that there are three aspects that teachers should scrutinize regarding the context of the learners, for instance, the gaps between the level of English of the students and the specific situations in which they are going to use the language, the need of learning how to communicate with others using the language appropriately according to the requirements of their discipline, and the expectations that learners have during the ESP course. Likewise, by examining the needs of the learners regarding ESP, instructors can teach successful ESP courses. Quesada and Zamora (2018) concluded that ESP courses increase motivation in professional populations because the learners study the aspects that they are going to need in their field. Globalization is one of the strongest reasons that makes people think about the importance of learning ESP properly. In fact, Williams (2014) stated that ESP has rapidly assumed an important position in this globalized world as a "functionalist" approach because ESP is useful to acquire the English 
linguistic skills that can be used in a professional context. Therefore, not applying ESP adequately implies negative consequences for the country and its citizens taking into account the fact that this approach provides them with the tools to be part of this globalized world.

\section{Effects of the Absence of ESP}

There are different effects or negative aspects as a result of not teaching ESP. Not only does the lack of the correct use of this approach affect students, but it also hinders employees' and companies' performance. Quesada and Zamora (2018) declared that it is unfavorable when students from different majors focus only on their fields but not on learning a second language during their learning process as in the case of the students of the electrical engineering major at UCR, Pacific Branch Campus, who manifested that in 2016, they did not have an English course on their syllabus. On the other hand, Ruiz (2014), in a study carried out at UCR, Guanacaste Branch Campus, established that there is a problem between the linguistic level and the labor competition level that students of ecological tourism should have in order to be in the labor market because superior levels of fluency are expected when facing real life situations, and a low level of complexity and communication skills in the learners is perceived. In fact, at least $40 \%$ of the interviewees affirmed that they are not prepared for the labor market because their English level is inefficient. Moreover, 30\% of the interviewees considered that they need the English course to obtain a job in the future. In summary, there is a growing concern among students from tourism, engineering, and other majors about learning specialized English because they are aware that in Costa Rica, several companies ask for bilingualism as one of the main requirements.

Costa Rica is a country that has undergone changes and has been forced to evolve due to globalization. For that reason, when a person is specialized in a specific field but does not master English, it may imply difficulties for the employee and for companies. Indeed, Barrantes (2009) asserted that:

Job interviews and language test results are frequently insufficient to certify the suitability of a candidate for a given job position. Unfortunately, many people are hired under those conditions. 
However, problems come up right after they start working. They do not achieve it very well when carrying out very specific tasks requiring language accuracy. (p. 2)

Not mastering the target language represents a problem for the resumes of future employees, and even a waste of time and money because sometimes they are forced to take and pay for extra courses in order to improve their communication skills in English to be hired or not to be fired from a company. Chacón (2010) stated that many companies have implemented strategies to train their staff in English; however, several businesses and employees are frustrated because the contents of the courses are too general to satisfy the linguistic requirements in professionals. As a conclusion, ESP is necessary in a developing country such as Costa Rica in order to fulfill the objectives of the labor market and globalization in general.

ESP is an approach that involves a significant learning process for those who want to learn the language because it provides them with different opportunities. Beshaj (2015) emphasized that "a foreign language speaker would be more comfortable in many situations if he /she knew the right vocabulary which is to be helpful and beneficiary in the job that this person is doing" (p. 2). Learners should become familiar with the ESP approach in order to improve their learning process because it is based on the needs that the fields require. Oh (2015) indicated that:

In the view of learners, a new approach and application to English education (e.g., task based interactional learning and feedback from their colleagues) might be uncomfortable for the learners given the common perception of learning they are accustomed to, and they may call into question the effectiveness of the approach given the limited time of instruction. (p. 12)

Consequently, at the beginning, the proper use of ESP could involve discomfort because learners could feel frustrated contemplating that applying correctly this approach can be more demanding than expected. Nevertheless, over time, the students could see the positive results and believe in the process. Overall, people should regard the 
implications of the absence of this approach to take into account the significance of ESP in Costa Rica.

\section{The Significance of ESP in Costa Rica}

Behind an ESP course, there should be a knowledgeable teacher who is fundamental to prepare the future professionals of a country. Saborio and Valenzuela (2009) asserted that:

The demand for employees with proficiency in English for general purposes (EGP) was overcome in recent years by the demand for individuals who besides having command of EGPs were proficient in English for specialized purposes (ESP). [...] neither public or private universities of the country have been able to keep up with the demand of training enough educators to administer appropriately the nation-wide EGP workshops, projects and programs, and even worse, there are still no programs aimed at training ESP teachers, except for the in-progress ESP project design being carried out by the Master's professional program in Second Languages and Cultures with Emphasis in English as a Foreign Language (MSLC) of the Universidad Nacional (UNA). (p. 2)

This means that the education system in Costa Rica is beginning to train professionals in the field. Moreover, Hernández (2008) indicated that Costa Rica needs to improve the English teaching field, and it is possible if the universities of the country prepare professionals to design ESP courses in order to teach English considering the professional profile of every discipline to be able to do specific tasks related to their jobs.

To highlight the effectiveness of learning English with ESP courses, Quesada and Zamora (2018) explained that within courses of this sort, the main aim for the learners is to speak the language, and this clear perspective allows them to face the learning process taking into consideration that learning the language is relevant to achieve their goals. As the previous quote stated, ESP is a promise for the learners to learn English successfully. Also, Barrantes (2009) explained that "ESP provides a way to make each factor accountable as well as complementary, and it is also a way to encourage students to become 
independent learners" (p. 7). These types of characteristics make this approach unique because it provides the learners with opportunities to enjoy their learning process and to be active learners. Hence, learning English with ESP courses bases its effectiveness on the way it works by motivating the learners, making them active participants, and establishing the target language as the main goal. However, Rodríguez (2006) recommended that "Costa Rica has to continue working on the strengthening of its public bilingual education and on the preparation of a large number of ESP professionals" (p. 11). This is because the country needs even more people specialized in this approach, and to reach this goal, different institutions are needed.

Globalization sees English as a language of commerce, politics, tourism, and other fields; on that ground, the implementation of ESP in both private and public institutions is necessary. For example, the Ministerio de Educación Pública $\left(\mathrm{MEP}^{3}\right)$, the Instituto Nacional de Aprendizaje $\left(\mathrm{INA}^{4}\right)$, public universities, and others have courses in which ESP is applied. Trigueros (2020) contended that MEP declared specific English teaching mandatory in the technical high schools of Costa Rica. He also mentioned that MEP offers a bilingual technical program in the following fields: service facilities management, bilingual secretariat, accounting, networking systems, software development, tourism, and others. On the other hand, INA also has English programs for each different field; for instance, INA (2018) took into account English for tourism, for telephone assistance, for facilities' service, for business, and others. Regarding public universities, they provide the Costa Rican population with syllabuses containing English focused on specific fields. Indeed, Trigueros (2020) described that Universidad Nacional has a master's degree course whose main objective is to respond to the development goals and the labor demands that Costa Rica has in terms of bilingual professionals specialized in specific disciplines. Hence, different public institutions are working on training professionals in ESP to meet the labor needs of the country considering that there are not enough professionals in the area.

Costa Rica is one of several countries around the world which has implemented ESP as a strategy to fulfill the necessities of different

3 Ministry of Public Education of Costa Rica for its acronym in Spanish

4 National Learning Institute of Costa Rica for its acronym in Spanish 
occupational areas. A correct use of this approach brings along a wide number of benefits or advantages to a country. For instance, in China, there are noticeable positive results regarding the appropriate implementation of ESP. Lin (2018) affirmed that "... the knowledge offered in ESP courses helped to extend their scope of knowledge. What they learned from ESP classes equipped them with sufficient knowledge for their respective professions..." (p. 52). In other words, learning ESP enhances the students' interest in acquiring more knowledge about the field and English, and it enables them to apply the language in a correct way when interacting with a foreign speaker. Countries such as Albania have appraised the importance of ESP in society. As Beshaj (2015) concurred, "[s]uch exchanges and interactions with the internationals increase the need to have people who know not just general English, but to have an extensive English vocabulary on various specific scientific, judicial, political, social fields" (p. 2). There is no doubt that ESP contributes to society in different and positive ways. In general, Costa Rica expects the same beneficial results that other countries have obtained for the implementation of this approach because it is noticeable the effectiveness of it in society.

\section{Conclusion}

Costa Rica is a developing country where the government strives to provide its citizens with a successful education. ESP is an approach that is worthy for this country because one of its goals is to be a bilingual nation. For instance, Saborio and Valenzuela (2009) asserted that “... Costa Rica has established as one of its main goals to create a bilingual national community that will be attractive for international market development and investment" (p. 4). This previous quote means that it is imperative to comprehend the aim of ESP in order to know about this unique approach that is fundamental to prepare students who need to master the language based on their professional profiles and teachers who are going to be able to design special English programs bearing in mind the needs of the learners regarding their specific fields. Likewise, assessing the effects of the absence of ESP and qualified professionals to teach and design syllabus for specific disciplines in the Costa Rican education system shows that this absence deprives the nation from more opportunities to learn the language as well as to obtain a job. 
ESP has changed throughout the years in Costa Rica; however, it is important to analyze that this approach is new in the country, and it is in a development process. As was previously mentioned, in Costa Rica, this approach started in 2006 and 2007 due to the requirements that the country began to face in the labor market. Some educational and labor institutions are starting to implement ESP; hence, it has different aspects that need improvements. According to Chacón (2010), there are idiomatic necessities that are presented, but unlike the past, the study of ESP was aimed to train professionals. Currently, it is considered in the contents of different educational programs. Therefore, despite the aspects to improve that ESP has, its evolution is noticeable because there are several case studies and investigations that have proved the effectiveness of this approach, for it has satisfied the requirements of some people successfully; also, it opens the doors to the possibility of learning a second language.

Applying ESP properly implies considering significant aspects of the learning process such as the needs, the professional profile, and the professional field of the students. Hence, one of the recommendations to start implementing this approach is to redesign the programs of university majors taking into account the professional profile, the context of the learners, and the opinion of qualified professionals in the area. Another recommendation for future instructors in this area is that they should commit themselves to encouraging the students to learn the target language employing this approach step by step in order to start getting familiar with either its proper use or its successful results. This is because implementing ESP incorrectly not only may affect or shock the students, but they also may drop out. Also, integrating this approach in the syllabus of different educational institutions and offering master's degree programs can make a difference in the future of Costa Rica as a country that has sought development throughout the years. 


\section{References}

Acosta, B., Brenes, C., \& Castro, J. (2015). Evaluating an English for specific purposes course for law students. Revista de Lenguas Modernas, 23, 263-283. https://doi.org/10.15517/RLM. V0I23.22350

Barrantes, L. (2009). A brief view of the ESP approach. Letras, 1(46), 1-7. https://www.revistas.una.ac.cr/index.php/letras/article/ view/1661

Basturkmen, H. (2010) Developing Courses in English for Specific Purposes. Palgrave Macmillan.

Beshaj, L. (2015). The growing importance of English for specific purposes (ESP) In Albanian higher education. International Journal on Studies in English Language and Literature, 3(6), 10-13. https://www.arcjournals.org/pdfs/ijsell/v3-i6/2.pdf

Chacón, M. (2010). Inglés con fines específicos. Revista Espiga, 9(20), 2-5. https://doi.org/10.22458/re.v9i20.1036

González, C. (2015). English for specific purposes: Brief history and definitions. Revista de Lenguas Modernas, 23, 379-386. https:// doi.org/10.15517/RLM.V0I23.22359

Hernández, A. (2008). El inglés en Costa Rica: requisito indispensable en un mundo globalizado. Revista Electrónica Actualidades Investigativas en Educación, 8(2), 3-8. https://doi.org/10.15517/ AIE.V8I2.9332

Hutchinson, T., \& Waters, A. (1987). English for Specific purposes. Cambridge University Press.

Instituto Nacional de Aprendizaje (INA). (2018). Contratación de servicios de capacitación y formación profesional en el subsector de idiomas según demanda. Instituto Nacional de Aprendizaje. https://www.ina.ac.cr/proveeduria/Documentos\%20compartidos/Tramite/Cartel_Ingles_(Audiencia). pdf\#search $=$ Contrataci $\% \mathrm{C} 3 \% \mathrm{~B} 3 \mathrm{n} \% 20 \mathrm{de} \% 20$ servicios $\% 20$ de $\% 20$ capacitaci $\%$ C3\%B3n $\% 20 \mathrm{y} \% 20$ formaci $\%$ C3\%B3n $\% 20$ profesional $\% 20$ en $\% 20$ e $1 \% 20$ subsector $\% 20$ de $\% 20$ idiomas $\% 20 \mathrm{seg} \% \mathrm{C} 3 \% \mathrm{BAn} \% 20$ demanda

Lin, F. (2018). Exploring the influence of English for specific purposes (ESP) curriculum on Chinese graduates' career [Unpublished 
Master's Thesis]. University of Windsor, Ontario, Toronto, Canada. https://scholar.uwindsor.ca/etd/7375/

Manley, M., Quesada, M. J., \& Zamora, S. (2019). Promoción del aprendizaje del inglés con fines específicos en diferentes sectores de la comunidad puntarenense: caso de los cursos de inglés para atención al turista. Revista de Lenguas Modernas, 30, 37-55. https://revistas.ucr.ac.cr/index.php/rlm/article/view/38889

Oh, Y. (2015). English for Specific Purposes for overseas sales and marketing workers in information technology. In J. Trace, T. Hudson, \& J. D. Brown (Eds.), Developing Courses in Languages for Specific Purposes (pp. 116-128). Honolulu: University of Hawai'i. http://hdl.handle.net/10125/14573

Quesada, M. J., \& Zamora, S. (2018). Una experiencia pedagógica en la enseñanza del inglés con fines específicos dentro del currículo universitario: caso de la carrera de ingeniería eléctrica, Universidad de Costa Rica, Sede del Pacífico. Revista de Lenguas Modernas, 29, 197-212. https://revistas.ucr.ac.cr/index.php/rlm/article/ view/36640

Rodríguez, X. (2006). Impact: an English for occupational purposes model designed for workplace language training in Costa Rica. Revista Comunicación, 15(1), 3-11. https://revistas.tec.ac.cr/index.php/comunicacion/article/view/1069

Ruiz, R. (2014). Propuesta para el rediseño del curso TE-0300 inglés conversacional I en turismo ecológico: Universidad de Costa Rica-Sede de Guanacaste. InterSedes: Revista de las Sedes Regionales, 15(30), 1-27. https://doi.org/10.15517/ISUCR. V15I30.14870

Saborio, I. \& Valenzuela, N. (2009). A proposal for the implementation of an English for specific purposes specialization in a master's degree program in second languages and cultures with emphasis in English as a foreign language. Revista de Lenguas Modernas, 11, 391-398. https://revistas.ucr.ac.cr/index.php/rlm/article/ view/9453

Sarmento, S., \& Bocorny, A. (2018). English for specific purposes (ESP). TESOL Press. https://www.researchgate.net/ publication/328964474_English_for_Specific_Purposes_ESP 
Trigueros, J. (2020). Reseña Histórica. Escuela de Literatura y Ciencias del Lenguaje. http://www.literatura.una.ac.cr/ resena-historica-maestria-linguistica

Trigueros, J. (2020). Maestría profesional en lingüistica aplicada con énfasis en la enseñanza del inglés como lengua extranjera y con énfasis en la enseñanza del inglés con fines especificos. Escuela de Literatura y Ciencias del Lenguaje. http://www.literatura.una. ac.cr/presentacion-maestria-linguistica

Williams, C. (2014). The future of ESP studies: building on success, exploring new paths, avoiding pitfalls. Open Edition Journals, 66(1), 137-150. https://doi.org/10.4000/asp.4616 